\title{
PENGEMBANGAN MADRASAH BERPARADIGMA PEMBANGUNAN BERKELANJUTAN
}

\author{
M. Imam Zamroni \\ Peneliti Pusat Studi Asia Pasifik Universitas Gadjah Mada \\ Email: imam_z@yahoo.com \\ Lies Rahayu WF \\ Fakultas Kehutanan Universitas Gadjah Mada \\ Email: lies_wf@yahoo.com
}

\begin{abstract}
This study aims to discover learning innovation for education for sustainable development (EfSD) that can bring sustainability regarding resources, the environmental, social and cultural. EfSD can teach morality to human beings as actors in their environment, pushing them to always be careful and wise in every activity that uses natural resources. The use of natural resources for the development is not only to meet short-term economic needs; it is therefore necessary to establish mana gement strategies that ensure sustainability, fairness, and efficiency. Efforts to achieve these strategies are mediated by interviewing people regarding environment ethical values, which in this case were implemented in children's education. The results of this research show that: (1) developing sustainable, development-paradigmatuc learning innovations must comply with the talents of students, which can be done by developing KTSP (curriculum for unit-level education); (2) the conservation of socio-cultural value is the basis to achieve a sustainable development paradigm; (3) innovations necessary for the creation of a sustainable development paradigm vary for each school background. This innovation is expected to guarantee the realization of a sustainable development paradigm in formal education; for the sake of intergenerational environment conservation.
\end{abstract}

\section{Keywords: Islamic Education, Madrasah and Sustainable Development}

\begin{abstract}
ABSTRAK
Penelitian bertujuan untuk menemukan inovasi pendidikan untuk pembangunan berkelanjutan (EfSD) yang dapat membawa pesan-pesan keberlanjutan terhadap nilai-nilai sumberdaya, lingkungan hidup, dan sosial budaya. EfSD dapat mengajarkan moralitas kepada umat manusia untuk selalu berhati-hati dalam setiap aktivitas yang bersinggungan dengan lingkungan. Penggunaan sumberdaya alam untuk pembangunan tidak hanya menitikberatkan pada ekonomi jangka pendek, namun juga harus menekankan pada aspek keberlanjutan, keadilan, dan efisiensi. Usaha untuk mencapai strategi tersebut harus diberikan dalam pendidikan anak. Hasil penelitian ini menunjukkan, (1) pengembangan inovasi pembelajaran berparadigma pembangunan berkelanjutan harus sesuai dengan talenta siswa, yang dapat dilakukan dengan mengembangkan KTSP (kurikulum tingkat satuan pendidikan); (2) pelestarian nilai sosial budaya menjadi basis untuk menuju paradigma pembangunan berkelanjutan; (3) inovasi menuju paradigma pembangunan berkelanjutan bervariasi untuk masing-masing latar belakang sekolah. Inovasi tersebut selanjutnya diharapkan dapat menjadi jaminan terwujudnya paradigma pendidikan pembangunan berkelanjutan pada jalur pendidikan formal, demi kelestarian lingkungan hidup yang berkesinambungan antargenerasi.
\end{abstract}

Kata kunci: Pendidikan Islam, Madrasah dan Pembangunan Berkelanjutan 


\section{PENGANTAR}

Pendidikan merupakan sebuah investasi jangka panjang yang memiliki peranan strategis dalam mengembangkan sumber daya manusia yang berkualitas. Berangkat dari hakekat manusia sebagai homo educandum, homo educabili dan homo educator, pendidikan yang berkualitas merupakan ujung tombak kemajuan bangsa. Melalui pendidikanlah, seseorang terstimulasi untuk melahirkan kualitas-kualitas terbaiknya sebagai manusia. Lahirnya sumber daya manusia yang berkualitas dan cosmopolitan adalah capaian pendidikan yang tidak bisa diciptakan secara instant.

DiIndonesia, citra pendidikan berkualitas unggul masih menjadi jauh dari harapan. Nandika mencatat keprihatinan pendidikan di Indonesia yang dari waktu ke waktu tidak kunjung mengalami perbaikan. Kondisi buruk pendidikan Indonesia tidak terlepas dari situasi dan kecenderungan makro dalam bidang ideologi, politik, ekonomi, sosial, dan budaya yang sedang mengalami masa transisi. Sebagai bukti, hasil studi UNDP (2004) dalam hal indeks pembangunan manusia (human development index) yang menunjukkan bahwa Indonesia berada di posisi ke-111 dari 177 negara adalah sebuah kenyataan pahit yang menjadi bagian dari cermin buram wajah pendidikan di Indonesia. Kompleksitas persoalan pendidikan mulai dari minimnya anggaran pendidikan, rendahnya kualitas dan pendapatan guru, kurangnya prasarana, mahalnya biaya pendidikan, tingginya lonjakan drop out dari siswa berlatar belakang keluarga miskin, angka buta huruf yang memprihatinkan serta semakin meningkatnya jumlah keluaran pendidikan yang menjadi penggangguran tidak bisa dipahami sematamata sebagai masalah teknis pendidikan. Persoalan-persoalan yang saling berkelindan ini apabila tidak tertangani secara sistemik, dapat bergulir menjadi bola salju persoalan yang menjadi boomerang bagi pendidikan
Indonesia.

Kenyataan ini pula yang terjadi dalam sistem pendidikan di madrasah. Madrasah sebagai salah satu institusi pendidikan islam di Indonesia, ternyata juga tidak luput dari persoalan pendidikan Indonesia. Banyak kalangan yang menilai perkembangan dan inovasi madrasah berjalan 'merambat' bahkan cenderung tertinggal. Oleh karenanya, inovasi terhadap madrasah sebagai salah satu pilar pendidikan Islam merupakan suatu jawaban. Model madrasah berparadigma pembangunan berkelanjutan tentunya membutuhkan kerangka pikir dan dasar epistemologi yang kuat, sehingga desain pembelajaran juga harus dilakukan secara kreatif dan inovatif untuk implementasi KTSP.

Hal ini dapat dilihat dari gagalnya pencanangan program wajar sembilan tahun yang terlihat dari fakta masih sekitar 20 persen anak usia sekolah menengah pertama yang masih belum bersekolah. Fakta lain yang juga cukup memprihatinkan adalah perbedaan angka partisipasi sekolah yang cukup besar antar daerah perkotaan dan perdesaan. Bahkan ditemukan kecenderungan adanya penurunan angka partisipasi sekolah menengah pertama pada kelompok masyarakat miskin.

Untuk mendapatkan bibit tunas bangsa yang cerdas dan berkualitas yang mampu yang berdaya saing global, namun dengan prinsip think globally, but act locally, peran pendidikan dasar melalui jalur formal atau sekolah menjadi sangat penting dan strategis. Kepekaan terhadap kebutuhan jangka panjang bagi kelangsungan kehidupan manusia yang lebih baik yaitu mempertimbangkan aspek kelangsungan lingkungan, manusia, dan ekonomi dapat diinternalisasi melalui jalur pendidikan formal. Sekolah tidak cukup lagi sekedar sebagai lembaga pendidikan yang mengajarkan pada anak didiknya pengetahuan exact dan non exact yang kemudian diujikan secara nasional dalam bentuk check point sebagai tolak ukur keberhasilan proses belajar mengajar atau tolak ukur kecerdasan seseorang. Hal ini 
karena pada saatnya nanti, anak-anak usia pendidikan dasar akan menghadapi dunia terus berkembang, yaitu persaingan global dan ragam persoalan akan menjadi bagian dari kehidupannya. Persaingan global menuntut peningkatan standar kompetensi. Dalam hal ini seseorang dituntut untuk lebih peka pada persoalan yang terjadi di sekitarnya termasuk dalam menciptakan ide-ide yang kritis, kreatif, dan solutif.

Education For Sustainable Development (EFSD) merupakan sebuah konsep pendidikan yang membawa misi pembentukan perilaku manusia yang bijaksana dalam menyikapi dan memperlakukan sumberdaya alam dan lingkungan hidup didasarkan oleh nilainilai etika moral guna mewujudkan suatu tatanan kehidupan yang harmonis di masa sekarang, dengan menjaga kelestariannya untuk kepentingan generasi yang akan datang. Sejak usia dini anak-anak di sekolah sudah diperkenalkan dengan pentingnya kelestarian lingkungan hidup yang berujung pada tumbuh dan berkembangnya kesadaran akan arti penting kelestarian lingkungan untuk kehidupan yang aman dan nyaman.

Jalur madrasah menjadi jembatan yang sangat penting untuk menyampaikan pesan pembangunan berkelanjutan, dengan cara membangun moral manusia agar dalam kehidupan menjunjung tinggi nilai etika lingkungan, serta mau bertindak dan berpartisipasi dalam mencari jawaban yang fundamental tentang keberlanjutan sumberdaya alam dan lingkungan hidup (Keraf, 2002). Dengan kata lain, pendidikan untuk pembangunan berkelanjutan itu pada hakekatnya tidak hanya memuat pesan-pesan lingkungan, tetapi juga kelestarian seluruh isi alam yang meliputi ranah sosial, budaya, ekonomi, dan politik. Dengan menekankan pada aspek keadilan sosial untuk kehidupan di muka bumi ini.

The Ministry of Education, Wellington (2003) menyatakan bahwa untuk mencapai keberlanjutan tersebut, terdapat empat konsep kuncipendekatan, yaitu (1). Interdependence, (2). Sustainabilit,; (3). Biodiversity, dan (4). Personal and social responsibility for action. Keempat konsep kunci tersebut memberikan petunjuk bahwa ketika membahas lingkungan hidup, kita harus berpijak pada basis ekosentris, yang menjunjung tinggi interdependence, yaitu nilai ekologis yang menyatakan bahwa makhluk hidup dan benda-benda abiotis lainnya saling terkait satu sama lain.

Kompetensi serupa ini semestinya ditanamkan sejak dini bagi para generasi muda. Paradigma pendidikan untuk pembangunan berkelanjutan merupakan paradigma pendidikan yang dikembangkan lima tahun terakhir ini merupakan salah satu alternatif solusi untuk menyiapkan generasi muda dalam merespon perkembangan zaman secara arif. Paradigma pendidikan ini pula yang diharapkan bisa menjawab persoalan pendidikan di Indonesia. Untuk itu penelitian ini akan mengangkat persoalan sejauhmana inovasi-inovasi yang sudah diupayakan dalam pendidikan dasar di madrasah ibtidaiyah (MI), khususnya di Yogyakarta, yang sudah mendukung program pembangunan berkelanjutan?. Adapun lokasi penelitian yakni di dua Madrasah Ibtidaiyah yang ada di kabupaten Bantul.

\section{PEMBAHASAN}

\section{Nilai Islam dan EfSD di Madrasah}

Pendidikan agama Islam merupakan instrumen yang paling strategis untuk memperkenalkan wawasan pembangunan berkelanjutan (sustainable development), kepada peserta didik. Islam merupakan rahmatal li al alamiin (rahmat bagi seluruh isi alam) yang meliputiaspek ekologi, ekonomi, sosial, budaya, dan politik. Maka dari itu, melestarikan seluruh isi alam ini untuk tujuan kebaikan adalah suatu keharusan bagi umat Islam, bahkan seluruh umat manusia di muka bumi ini. Spirit nilainilai agama tersebut sebenarnya selaras dengan pembangunan berkelanjutan dan ayat suci $\mathrm{Al}$ Qur'an (QS. Al A'raaf 7:56). Spirit pendidikan 
Islam selalu mengajarkan keselarasan dan kearifan dalam kehidupan umat manusia dapat dijadikan sebagai basis yang fundamental untuk mendesain kurikulum pendidikan berwawasan pembangunan berkelanjutan (education for sustainable development atau EFSD), sebagai kurikulum inti (core curriculum) di dalam madrasah.

Dalam praktik pembelajaran di madrasah, unsur-unsur pembangunan berkelanjutan diimplementasikan ke dalam mata pelajaran yang relevan. Seperti dalam pembelajaran mata pelajaran Ilmu Pengetahuan Alam (IPA) yang didalamnya terdapat unsur pengenalan dan pemahaman kepada peserta didik tentang lingkungan. Kemudian guru menyampaikan materi di dalam kelas secara teoritik dan kemudian dalam kesempatan pertemuan yang lain, guru bersama dengan siswa melakukan kunjungan ke alam. Dalam hal ini, guru menekankan materi untuk kelestarian lingkungan kepada siswa. Lingkungan yang ada di sekitar madrasah dapat dijadikan sebagai media pembelajaran yang efektif.

Dalam hal ini, guru memaknai pembelajaran yang dilakukan dari dua sisi, yaitu sisi pembangunan berkelanjutan, sisi ajaran, dan norma-norma Islam yang terkait dengan kelestarian lingkungan. Inilah satu model pendidikan Islam terpadu (Islamicintegrated education). Mempunyai dua orientasi mendasar, yakni orientasi duniawi dengan melestarikan alam dan orientasi ukhrowi dengan selalu memikirkan kehidupan yang akan datang yang diyakini sebagai kehidupan yang lebih kekal dan abadi. Sebagai basis pengembangan pembelajaran berbasis pendidikan untuk pembangunan berkelanjutan, maka guru harus memahami prinsip dan tujuan utama kurikulum yang ada di madrasah.

Dasar normatif ini seharusnya dijadikan sebagai epistemologi pengembangan madrasah yang dikontekstualisasi dengan situasi dan kondisi kekinian di sekitar tempat belajar. Kerjasama yang baik antara madrasah dengan masyarakat lokal sangat penting untuk menunjang pembelajaran berparadigma pada pembangunan berkelanjutan dengan tetap berpegang teguh pada standar kurikulum yang ada seperti KTSP.

\section{EfSD di Madrasah Sebagai Best Practices}

Penelitian ini dilakukan di dua madrasah yang ada di kabupaten Bantul, Yogyakarta yakni Madrasah Ibtidaiyah Negeri (MIN) Jejeran dan Madrasah Ibtidaiyah Ma'arif Giriloyo. Satu madrasah berstatus negeri dan yang kedua berstatus swasta. Pemilihan dua madrasah tersebut didasarkan pada inovasi yang sudah dilakukan oleh madrasah ke arah pembangunan berkelanjutan karena madrasah yang ada di Bantul tidak semuanya melakukan inovasi dan pengembangan ke arah pembangunan berkelanjutan. Berdasarkan hasil penelitian yang dilakukan terdapat beberapa inovasi di dua madrasah yang berorientasi pada pembangunan berkelanjutan.

\section{Inovasi keberlanjutan ekonomi}

Inovasi pembelajaran ekonomi di madrasah menekankan pada aspek kejujuran dan moralitas dengan menggunakan pendekatan afektif. Media yang digunakan adalah dengan membangun 'kantin kejujuran'. Pada ranah afektif tercermin dalam bangunan kejujuran dan moralitas saat para siswa melakukan transaksi di kantin. Para siswa diberikan pemahaman bahwa ketidakjujuran akan mengakibatkan kerugian terhadap orang lain. Anak-anak sudah diajarkan untuk berpikir jangka panjang dan dampak terhadap perbuatan yang dilakukan. Nilainilai pembelajaran dalam aktivitas ekonomi yang dilakukan oleh siswa inilah yang menjadi poin penting bagi siswa untuk selalu memikirkan orang lain terhadap tindakan yang dilakukan.

Di kantin kejujuran, praktik jual beli dilakukan dengan model selfservice. Para siswa mengambil makanan yang diminatinya dan kemudian membayarnya dengan meletakkan 
uang untuk membayar makanan di tempat yang telah disediakan oleh penjaga kantin. Jika terdapat uang kembalian yang harus diambil, anak-anak juga mengambil uang kembalian tersebut di tempat yang telah disediakan. Penjaga kantin hanya bertugas mengawasi transaksi yang dilakukan oleh para siswa dan memberikan informasi harga makanan/ barang yang dijual di kantin. Terbangunnya sikap jujur di dalam diri siswa menjadi tujuan dibangunnya sistem jual-beli yang khas dan unik. Adanya kantin kejujuran bukanlah sebagai spirit akumulasi kapital sebagaimana laiknya ekonomi kapitalis, namun di dalam kantin kejujuran terdapat spirit edukasi bagi siswa yang mengedepankan nilai-nilai kejujuran dan keadilan sosial.

Kejujuran tidak hanya ada dalam pikiran maupun teori yang disampaikan di kelas, tetapi di madrasah ini kejujuran juga dipraktikkan dalam kehidupan sehari-hari, khususnya dalam praktik jual beli. Kejujuran menjadi hal yang sangat penting bagi bangsa Indonesia yang sedang mengalami krisis moral yang ditandai dengan semakin banyaknya kasus korupsi. Kesadaran akan pentingnya kejujuran tidak hanya sebagai alat dalam pendidikan, melainkan merupakan proses dialogis yang mengantarkan individuindividu secara bersama-sama untuk memecahkan masalah-masalah eksistensial manusia.

Di samping pembelajaran ekonomi yang berbasis pada kejujuran kepada para siswa dengan mempraktikkan secara langsung, para siswa juga diajarkan teoriteori ekonomi dasar sebagaimana yang ada di madrasah pada umumnya di dalam kelas. Guru terkadang juga mengajak kepada siswa untuk melihat praktik transaksi jual-beli yang ada di pasar tradisional yang dilakukan oleh para pedagang pasar. Mereka dilatih untuk dihadapkan secara langsung kepada realitas faktual dalam kehidupan seharihari. Refleksi menjadi bagian yang sangat penting untuk diperkenalkan kepada siswa tentang kehidupan yang kompleks yang dialami oleh para pedagang pasar tradisional dengan mengacu pada teori-teori ekonomi yang dipelajari di dalam kelas, sehingga para siswa tidak terlalu kesulitan mempelajari teori-teori ekonomi yang rumit karena sudah menyaksikan realitasnya di lapangan.

Dalam konteks kehidupan berkelanjutan, para siswa juga diajak untuk mengamati praktik ekonomi yang tidak mencerminkan sustainabilitas yang dilakukan oleh warga yang ada di sekitar sekolah dan tentunya dapat mengancam kehidupan orang lain. Terdapat penambang tanah yang digunakan sebagai bahan untuk mencetak batu bata, batako, maupun material lain sebagai bahan bangunan. Tanah sifatnya tidak berkembang, jika dilakukan pengerukan secara terus menerus, maka kondisi tanah akan rusak dan mengakibatkan usaha sektor ekonomi seperti ini akan berhenti. Bahkan juga menyebabkan terjadinya bencana bagi warga di sekitar lokasi penambangan.

Kontekstualisasi aktivitas ekonomi yang mencerminkan pada pembangunan berkelanjutan dan aktivitas ekonomi yang eksplotatif ditelaah dengan menggunakan teori-teori ekonomi yang diajarkan di dalam kelas yang dipadukan dengan ajaran agama Islam. Siswa dibekali dengan pengetahuan umum dan pengetahuan agama dengan menekankan aspek keberlanjutan untuk kehidupan yang akan datang.

\section{Kelestarian lingkungan}

Lingkungan menjadi perhatian bagi madrasah, terutama untuk menjaga kebersihan dan melestarikannya. Anak-anak didorong untuk selalu menjaga kebersihan dengan membuang sampah pada tempat yang telah disediakan. Anak-anak juga diajarkan untuk mengolah sampah menjadi pupuk organik dan kemudian digunakan sebagai media untuk menanam tanaman, seperti tanaman sayuran, tanaman obat-obatan, dan tanaman bunga. Di sinilah mereka belajar mengaplikasikan 
teori yang didapatkan di dalam kelas untuk pembangunan berkelanjutan dengan tidak memutus siklus di muka bumi ini.

Dalam praktik penanaman, siswa ditumbuhkan rasa handarbeni (rasa memiliki) terhadap tanaman yang ditanam, sehingga jika nanti tanaman tersebut berbuah, maka siswa yang menanam berhak untuk memetik buahnya. Partisipasi siswa dalam pengelolaan lingkungan di sekolah merupakan hal yang sangat penting yang didukung oleh berbagai fasilitas seperti adanya 14 kamar mandi dan WC untuk siswa dan dua kamar mandi untuk guru dan karyawan serta satu ruang UKS. Pelestarian lingkungan di madrasah harus didukung oleh semua pihak dan bersifat partisipatif agar dapat dilakukan secara berkelanjutan.

Di madrasah banyak sekali tanaman yang dibudidaya dan siswa yang menjadi lokomotifnya. Siswa dalam hal ini dilibatkan untuk merawat seperti menyiram tanaman, membersihkan gulma, dan melakukan pemupukan jika dibutuhkan. Bahkan terkadang siswa juga mengusulkan tanaman yang harus ditanam dengan membawa tanaman dari rumah. Dalam hal ini guru berperan sebagai pendamping dan fasilitator dalam kegiatan untuk mengarahkan aktivitas siswa. Aktivitas melestarikan lingkungan dalam pembelajaran siswa biasanya dikombinasikan dengan pendidikan kesehatan untuk siswa karena lingkungan yang bersih akan menciptakan hidup yang sehat.

Pendidikan kesehatan dilaksanakan dalam pembelajaran Pendidikan Jasmani dan Olah Raga Kesehatan (Penjaskes), dan sosialisasi kesehatan setiap hari selama 5 menit di awal pembelajaran yaitu jam pertama. Di dalam proses pembelajaran Penjaskes (Pendidikan Jasmani dan Kesehatan) yang bersifat praktik, terkadang kegiatan anakanak diarahkan untuk membantu menyiram tanaman dan merawatnya. Dalam mata pelajaran yang lain, hampir secara keseluruhan
- dalam pertemuan tertentu - terdapat dimensi kelestarian lingkungan. Seperti dalam mata pelajaran Ilmu Pengetahuan Alam (IPA), Bahasa Jawa, Qur'an Hadits, Sejarah Kebudayaan Islam (SKI), dan Ilmu Pengetahuan Sosial (IPS). Berikut dijelaskan inovasi pembelajaran di sejumlah mata pelajaran yang berdimensi pelestarian lingkungan.

Berdasarkan tabel di atas, maka dapat diketahui bahwa terdapat lima mata pelajaran yang dikontekstualisasikan dalam praktik pembelajaran untuk kelestarian lingkungan. Metode pembelajaran yang digunakan oleh masing-masing guru juga beragam. Terdapat guru yang mengajak para siswa untuk mengamati secara langsung fenomena alam yang ada di sekitar madrasah seperti di area persawahan maupun perkebunan. Di samping itu juga terdapat guru yang hanya melaksanakan pembelajaran di ruang-ruang kelas yang ada di madrasah. Di madrasah memang memadukan antara pembelajaran di dalam kelas dengan pembelajaran di luar kelas yang sifatnya kontekstual.

Kontekstualisasi pembelajaran pada kelestarian lingkungan tidak hanya ditemukan pada mata pelajaran IPA dan IPS, tetapi juga pada mata pelajaran agama (Qur'an dan Hadits) dan muatan lokal (Bahasa Jawa). Nilai-nilai ajaran agama Islam dan budaya lokal mempunyai spirit dalam melestarikan lingkungan, sehingga kontekstualisasi materi pembelajaran pada fenomena empirik kepada peserta didik agar mereka dibekali dengan pemikiran jangka panjang dan berkelanjutan. Di samping itu, antara lingkungan alam dan sosial mempunyai hubungan timbal balik yang harus dikelola secara seksama.

Inovasi pembelajaran untuk kelestarian lingkungan ini juga harus didukung dengan sistem kelembagaanyang baik danmendukung pembelajaran kepada siswa yang menekankan pada aspek kelestarian lingkungan. Di MIN Jejeran terdapat program kerja $10 \mathrm{~K}$, yakni kebersihan, keamanan, ketertiban, keindahan, 
Tabel 1.

Klasifikasi Rencana Pelaksanaan Pembelajaran (RPP) Berwawasan Lingkungan di Madrasah

\begin{tabular}{|c|c|c|c|}
\hline No. & Mapel & Materi ajar & Aspek wawasan lingkungan \\
\hline 1 & IPA & $\begin{array}{l}\text { Perubahan sifat-sifat } \\
\text { benda }\end{array}$ & $\begin{array}{l}\text { - Memahami pentingnya pelestarian jenis mahluk hidup untuk } \\
\text { mencegah kepunahan. } \\
\text { - Mengidentifikasi faktor-faktor yang menentukan pemilihan benda/ } \\
\text { bahan untuk tujuan tertentu (karet, logam, plastik) dalam kehidupan } \\
\text { sehari-hari. }\end{array}$ \\
\hline 2 & IPA & $\begin{array}{l}\text { Bagian-bagian } \\
\text { tumbuhan dan } \\
\text { fungsinya }\end{array}$ & $\begin{array}{l}\text { - Memahami hubungan antara struktur bagian tumbuhan dan } \\
\text { fungsinya } \\
\text { - Mengidentifikasi bagian-bagian tumbuhan dan fungsinya dengan } \\
\text { melakukan praktik secara langsung terhadap beberapa contoh } \\
\text { tumbuhan }\end{array}$ \\
\hline 3 & IPA & $\begin{array}{l}\text { Memelihara dan } \\
\text { melestarikan hutan }\end{array}$ & $\begin{array}{l}\text { - Menyebutkan jenis sumber daya alam yang berasal dari hutan dan } \\
\text { manfaatnya } \\
\text { - Menjelaskan perilaku yang benar dalam upaya memelihara hutan } \\
\text { - Melakukan pengamatan secara langsung dan diskusi kelompok }\end{array}$ \\
\hline 4 & $\begin{array}{l}\text { Bahasa } \\
\text { Jawa }\end{array}$ & $\begin{array}{l}\text { Membaca, memahami } \\
\text { dan menangggapi teks } \\
\text { tentang lingkungan } \\
\text { hidup }\end{array}$ & $\begin{array}{l}\text { - Membaca kata, frase dan kalimat dengan ucapan dan intonasi yang } \\
\text { benar pada teks sederhana yang berkaitan dengan lingkungan } \\
\text { hidup. } \\
\text { - Memahami teks berbahasa jawa sederhana yang berkaitan dengan } \\
\text { lingkungan hidup } \\
\text { - Memberikan tanggapan terhadap wacana yang terkandung dalam } \\
\text { teks sederhana berbahasa jawa tentang lingkungan hidup. }\end{array}$ \\
\hline 5 & $\begin{array}{l}\text { Qur'an } \\
\text { Hadits }\end{array}$ & $\begin{array}{l}\text { Hadits tentang } \\
\text { kebersihan }\end{array}$ & $\begin{array}{l}\text { - Melafalkan dan memahami hadits tentang kebersihan } \\
\text { - Guru menjelaskan pentingnya menjaga kebersihan lingkungan }\end{array}$ \\
\hline 6 & SKI & $\begin{array}{l}\text { Cinta Rasul terhadap } \\
\text { hewan dan larangan } \\
\text { islam membunuh hewan } \\
\text { sewaktu ihram }\end{array}$ & $\begin{array}{l}\text { - Memprakarsai sikap yang baik terhadap hewan dan tumbuhan } \\
\text { - Mengenal suri tauladan yang baik dalam memelihara hewan dan } \\
\text { melestarikannya dalam kehidupan sehari-hari. }\end{array}$ \\
\hline 7 & IPS & $\begin{array}{l}\text { Lingkungan alam dan } \\
\text { buatan }\end{array}$ & $\begin{array}{l}\text { - Memelihara lingkung } \\
\text { - Mempraktekkan peles }\end{array}$ \\
\hline 8 & IPA & Daur air & $\begin{array}{l}\text { - Melakukan pembiasaan cara menghemat air dan cara mengatasi } \\
\text { kekurangan air } \\
\text { - Mengamati gambar danau yang kekeringan karena kekurangan air }\end{array}$ \\
\hline
\end{tabular}

Sumber: dokumen MIN Jejeran, 2009. sudah diolah.

Keterangan:

IPA : Ilmu Pengetahuan Alam

SKI : Sejarah Kebudayaan Islam

IPS : Ilmu Pengetahuan Sosial

kekeluargaan, kerindangan, kesehatan, keagamaan, keberlanjutan, dan keserasian. Di samping merumuskan program kerja yang menunjang kelestarian lingkungan, MIN Jejeran juga membentuk tim kerja madrasah berwawasan lingkungan dengan Surat Keputusan kepala madrasah nomor: MI.L/14/PP.00.4/55/2006.

Program kerja tersebut juga didukung oleh peraturan dan himbauan-himbauan yang dikeluarkan oleh madrasah, seperti larangan merokok di madrasah, anjuran membuang sampah pada tempatnya, membersihkan kamar mandi, dan lain sebagainya. Pengelolaan sampah dilakukan dengan mengatur jadwal siswa dalam kegiatan Jumampah (juru pengambil dan pengumpul sampah), sedangkan untuk kebersihan kamar mandi dan bebas dari jentik diatur dalam kegiatan Jumantik (juru pemantau jentik) yang dilakukan oleh siswa secara berkala. Kegiatan Jumantik ini didukung dengan program Dokcil (Dokter Kecil) yang bekerjasama dengan tim dari Puskesmas (Pusat Kesehatan Masyarakat) setempat. Pendek kata, untuk menciptakan 
madrasah yang berkualitas tentunya membutuhkan suatu kepemimpinan yang baik dan transformatif.

Berbagai kegiatan tersebut bertujuan untuk menanamkan tanggung jawab kepada siswa untuk menjaga kelestarian lingkungan, kebersihan, dan kesehatan. Di samping itu, metode pembelajaran dengan cara mempraktikkan secara langsung akan lebih mudah dipahami oleh siswa daripada hanya sekedar teori di dalam kelas. Pembelajaran kontekstual melibatkan para siswa dalam aktivitas penting yang membantu mereka mengaitkan pelajaran akademis dengan konteks kehidupan nyata yang mereka hadapi. Dimensi pembangunan berkelanjutan tercermin dari upaya pelestarian lingkungan yang dilakukan oleh civitas akademika di madrasah dengan mendorong partisipasi semua pihak.

\section{Kelestarian sosial-budaya masyarakat}

Pada ranah sosial-budaya inovasi yang dilakukan oleh madrasah adalah usaha secara sistematis untuk melestarikan budaya membatik yang ada di lingkungan MI Ma'arif Giriloyo. Desa Giriloyo dikenal oleh masyarakat sekitar sebagai pusat pengrajin batik di kabupaten Bantul. Namun sampai saat ini, para pengrajin tersebut hanya diminati oleh generasi tua, sedangkan kelompok usia muda tidak tertarik untuk menekuni dunia batik. Akhirnya aktivitas membatik terus mengalami penurunan karena tidak ditopang oleh kelompok usia produktif yang ada di desa. Hal ini dikarenakan tidak adanya transformasi sosial aktivitas membatik antar-generasi.

Berdasarkan fenomena tersebut, MI Ma'arif Giriloyo mencoba untuk memperkenalkan proses membatik kepada para siswa dengan memasukkan kegiatan membatik ke dalam kurikulum ekstrakurikuler di madrasah. Para pembatik menjadi pemateri bagi siswa yang ingin belajar membatik dengan didampingi oleh guru kesenian yang ada di madrasah. Masyarakat lokal yang ada di sekitar madrasah yang mempunyai keahlian membatik berusaha memperkenalkan motif dan corak batik yang selama ini menjadi identitas batik di desa Giriloyo. Di samping itu, anak-anak juga diberikan ruang kebebasan untuk berkreasi dan menciptakan motif batik yang baru.

Keterikatan yang kuat antara MI Ma' arif Giriloyo dengan lingkungan sosial di sekitarnya menciptakan suatu bentuk interaksi yang positif bagi kelangsungan kegiatan pendidikan. Bentuk interaksi yang terwujud memperlihatkan peran MI Ma'arif Giriloyo sebagai lembaga pendidikan sekaligus jembatan budaya antar generasi. Partisipasi masyarakat menjadi hal yang sangat penting dalam melestarikan nilai-nilai budaya lokal dan sekaligus mentransformasikan kepada anak-anak di madrasah.

Dalam konteks partisipasi masyarakat untuk melestarikan budaya lokal dan sebagai bentuk penguatan sosial ke arah pembangunan berkelanjutan diperlukan pelembagaan sosial. Institusi sosial di madrasah seperti komite madrasah yang dijadikan sebagai pijakan tangga partisipasi masyarakat terkadang masih dianggap sebagai sesuatu yang elitis bagi masyarakat desa di sekitar madrasah. Oleh karenanya, di MIN Jejeran berusaha menciptakan struktur mediasi untuk meningkatkan partisipasi masyarakat di madrasah.

Di bawah komite madrasah terdapat kelompok sosial yang disebut dengan patembayan dan paguyuban orangtua siswa. Peguyuban sebagai Kelompok sosial ini mempunyai tanggungjawab terhadap kelas anak-anaknya, jadi dalam setiap kelas yang ada di madrasah mempunyai paguyuban orangtua siswa yang otonomi. Adapun patembayan sebagai kelompok sosial di atas paguyuban mempunyai tanggungjawab terhadap madrasah secara keseluruhan yang dikoordinasikan dengan komite madrasah dan stakeholder di madrasah.

Kelompok-kelompok sosial tersebut 
juga melakukan penggalian dana untuk pembangunan madrasah dengan prinsip pengelolaan yang transparan dan akuntabel. Pembangunan di madrasah dapat dilakukan secara berkelanjutan karena didukung dengan partisipasi masyarakat lokal yang cukup kuat. Tingkat partisipasi masyarakat lokal yang cukup tinggi untuk menciptakan pendidikan yang berkualitas ini tentunya memerlukan pengelolaan dan inovasi yang sesuai dengan konteks lokal yang mampu mengakomodasi aspirasi warga. Begitu pula dengan pola pengembangan madrasah berbasis pembangunan berkelanjutan harus ditopang dengan tingkat partisipasi masyarakat yang cukup kuat.

\section{SIMPULAN}

Inovasi pendidikan berparadigma pembangunan berkelanjutan (education for sustainable development) di madrasah dapat dikontekstualisasikan dengan nilai-nilai ajaran agama Islam yang bersumber pada Al Qur'an dan Hadits. Seperti menjelaskan tentang ayat suci Al Qur'an maupun Hadits nabi yang relevan dengan aspek budaya lokal dan kewajiban manusia untuk menjaga alam beserta seluruh isinya. Dalam praktik pembelajaran, maka aspek lokalitas turut mewarnai praktik pembelajaran yang dilakukan di madrasah. Inovasi pendidikan Islam untuk pembangunan berkelanjutan sebagai bentuk investasi jangka panjang untuk berkontribusi kepada kehidupan umat manusia di muka bumi ini agar lebih aman, nyaman, dan berkeadilan sosial.

Terdapat tiga aspek penting inovasi yang sudah dilakukan di dua madrasah yakni: ekonomiberkelanjutan, kelestarian lingkungan dan kelestarian sosial-budaya masyarakat lokal. Aspek lokalitas dan modal sosial yang ada madrasah mempunyai kontribusi penting terhadap arah pengembangan inovasi pendidikan yang dilakukan. Salah satu inovasi pendidikan berparadigma pembangunan berkelanjutan ini dilakukan dengan menggunakan metode pembelajaran CTL (contextual teaching and learning) karena Education for Sustainable Development (EFSD) bukanlah satu materi tersendiri yang ada di sekolah, melainkan terintegrasi terhadap mata pelajaran yang ada di madrasah. Pembelajaran kontekstual menjadi metode yang sangat tepat dalam improvisasi pendidikan ke arah pembangunan berkelanjutan.

Inovasi menuju paradigma pembangunan berkelanjutan bervariasi untuk masing-masing latar belakang madrasah. Inovasi tersebut selanjutnya diharapkan dapat menjadi jaminan terwujudnya paradigma pendidikan pembangunan berkelanjutan demi kelestarian lingkungan alam, sosial, dan budaya yang berkesinambungan antar-generasi. Bahasa menjadi bagian dari sistem kebudayaan, maka pengajaran bahasa jawa merupakan salah satu aspek praktik pembelajaran untuk kelestarian budaya lokal.

Pendidikan Islam dengan berparadigma pembangunan berkelanjutan, maka secara bersama-sama mempunyai komitmen untuk berkontribusi dalam mewujudkan kehidupan yang lebih baik, dunia yang lebih aman-nyaman bagi kita semua, baik sekarang maupun di masa yang akan datang bagi anak cucu kita. Ini merupakan sebuah pemahaman tentang kompleksitas dan diversitas secara komprehensif serta pemahaman tentang bagaimanacaramengubahsegala perkembangan dan pengembangan ke arah sustainibilitas, juga dilaksanakan melalui perencanaan dan pelaksanaan yang bijaksana dengan memadukan antara nilai-nilai pendidikan agama Islam dengan nilai-nilai pembengunan berkelanjutan.

\section{DAFTAR PUSTAKA}

Anonimous, 2003, The Key Concept Underlying Environmental Education. Wellington, The Minister of Education, New Zealand.

Darmaningtyas, 2007, Realitas Pemberlakukan UAN/UN. EDUKASI Jurnal Penelitian Pendidikan Agama dan Keagamaan, 
Vol. 5 (1): hlm. 41-54.

Idi, Abdullah, 1999, Pengembangan Kurikulum Teori dan Praktik, Jakarta: Media Pratama.

Johnson, Elaine B, 2009, Contestual Teaching anda Learning; Menjadikan Kegiatan Belajar-Mengajar Mengasyikkan dan Bermakna, Bandung: Mizan Learning Center (MLC).

Karni, Asrori S, 2009, Etos Studi Kaum Santri; Wajah Baru Pendidikan Islam, Bandung, Mizan.

Keraf, A. Sony, 2006, Etika Lingkungan, Jakarta: Kompas.

May, Robert M, 2008, The Britanica Guide to Climate Change; An Unbiased Guide to The Key Issue of Our Age, USE, Running Press Book Publishers.

Muhaimin (ed), 2008, Pengembangan Model
Kurikulum Tingkat Satuan Pendidikan (KTSP) pada Sekolah dan Madrasah, Jakarta: Rajawali Perss.

Mulyasa, H.E, 2007, Manajemen Berbasis Sekolah; Konsep, Strategi dan Implementasi, Bandung: Rosdakarya.

Nandika, Dodi, 2007, Pendidikan di Tengah Gelombang Perubahan, Jakarta: LP3ES.

Raihani. 2010, Kepemimpinnan Sekolah Transformatif, Yogyakarta: LkiS.

Smith A, William, 2001, Conscientizacao; Tujuan Pendidikan Paulo Freire. Yogyakarta: Pustaka Pelajar.

Susilo, Rachmad K. Dwi, 2009, Sosiologi Lingkungan, Jakarta: Rajawali Press.

Trianto, 2009, Mendesain Model Pembelajaran Inovatif-Progresif; Konsep, Landasan dan Implementasinya pada Kurikulum Tingkat Satuan Pendidikan (KTSP), Jakarta: Kencana. 